Research.

\title{
STRATEGY FORMULATION OF PT. BANK PEMBANGUNAN DAERAH KALIMANTAN TIMUR
}

\author{
Sumardjono ${ }^{1, *}$, Rio Cipto Sulton ${ }^{2}$ \\ Department of Management, Economic College of Binaniaga, Bogor, Indonesia \\ sdjonref18@gmail.com (Sumardjono)
}

\begin{abstract}
* Corresponding author
Received: October 25, 2018; Accepted: November 12, 2018; Published: December 31, 2018

To cite this article: Sumardjono and Rio Cipto Sulton, Strategy Formulation of PT. Bank Pembangunan Daerah Kalimantan Timur, The Management Journal of BINANIAGA, Vol. 03, No. 02, December 2018, pp. 55 70.
\end{abstract}

Abstract. The purposes of this study are: 1. To find out the factors which become the main strengths and weaknesses of PT. Bank Pembangunan Daerah Kalimantan Timur 2. To find out the factors which become the opportunities and threat weaknesses of PT. Bank Pembangunan Daerah Kalimantan Timur 3. To find out the right strategies to be implemented in PT. Bank Pembangunan Daerah Kalimantan Timur. The population in this study is a group of management officials of PT. Bank Pembangunan Daerah Kalimantan Timur with total 5. headquarter employees. The results of this study show that the alternative strategy which can be implemented by management of PT. Bank Pembangunan Daerah Kalimantan Timur management based on the results of Quantitative Strategic Planning Matrix (QSPM), i.e. internal and external long-term implementation based on TAS (Total Atractiveness Score), i.e. Product innovation $3.15+3.07=6,22$ Market research $2.69+2.98=5.67$ Increasing the number of customers $2.89+3.02=5.91$ Improvement of services 2.79 $+2.83=5.62$, whereas the Implementation of Medium-term strategies are: 1 . Providing information about the product provision that applied according to the provisions of Bank Indonesia 2. Providing up-to-date knowledge products enable the employees to be able to control the banking industry 3. Promoting activities in each corner of the market in the field of education, tourism and collaboration with local governments 4. Providing convenience in providing credit loans to customers according to their needs. While the Short-term implementations are: 1. Provide regular training enable the employees to maintain and improve customer service 2. Maintain the existing products and improve product innovation to anticipate new products of competitors 3. Perform promotional activities through print media and electronic media by using brief and clear discussion in order to attract customers and facilitate with a maximum budget 4. Controlling financial expenses and manage capital in order to create profits and anticipate liquidation.

Key words : BPD Kalimantan Timur - Strategy Analysis

\section{PREFACE}

\section{Background}

Economic conditions in the era of globalization bring changes and development in various aspects of life. This also has implications for the development of the existing banking system, the emergence of new banks managed by regional governments. The bank is one of the most important charts in the modern economic system because it has a strategic position as an intermediary, i.e. collecting funds from people and re-distribute

Sumardjono and Rio Cipto Sulton. Strategy Formulation of PT. Bank Pembangunan Daerah Kalimantan Timur 
to those in need and supporting the payment system. Because of this function, the bank is the driving force of economic that will support and sustain economic activities in society.

Economic world crisis in this era, forcing the banks in the country to make a strategy to maintain their business. Many economists also predict that if banks are not ready to deal with this, the impact will be very large on the bank development. Even the current global crisis, it is feared that it will be worse than the economic crisis in 1997. The strategy undertaken by banks to deal with this, basically formed on how to control the existing of market share, despite the economic growth is unstable that causes deflation in the market as well.

One of the efforts made by banking sector is to fix its features of product. Besides, rising savings and interest rates of loan is the final solution so that people do not compete to take the funds. The invention of banking products with more sophisticated features should be offered to customers then it attracts customers or prospective customers. And besides, new products are also created with various features according to current market. All of these efforts are carried out to answer market needs so that the banks can indirectly reach a wider market share. Banking is a means that is able to facilitate all business transactions, both financially and non-financially. The more growing someone's "business", the greater the need and reletionship to the banking world.

The point is there are many strategies have been carried out by the banks to become the best bank and capable to dominate the market, such as:

1. Promoting and giving door prize to customers as an effort in order to attract people saving at the bank.

2. Developing in the field of banking technology to fulfil social needs.

3. Improve convenient and customer service, from the way how employees serve customers to the comfortbale office room is a target of improvement.

4. Offering competitive interest rates.

5. Opening branch offices, units, services, extending ATM machines, and offering various kinds of facilities for prospective customers.

PT. Bank Pembangunan Daerah Kalimantan Timur is one of Regional Companies of Provincial Government and Districts in East Kalimantan as a thought of East Kalimantan Governor, A. Moeis Hasan, established on October 14, 1965 based on Perda. Tingkat I Kalimantan Timur No. 03 / PD164, September 19, 1964 which had been approved by the Minister of Home Affairs No.9 / 0 / 8-45 April 1, 1965. And Perda (Regional Regulation) has been changed into Perda. Kalimantan Timur No. 02 / 2002, February 1, 2002 concerning Bank Pembangunan Daerah Kalimantan Timur, Perda No. 02 of 2006 dated April 26, 2006 concerning the First Amendment to East Kalimantan Provincial Regulation Namor 02 of 2002.

Every bank has a strategy pattern that is almost the same between one another. What distinguishes it is only in determining "top priority". In this paper we will discuss the strategies carried out by banks to win market competition through the creation of reliable marketers as the spearhead of bank expansion into the community. Banking in this case does not just stay silent waiting for customers to come to the bank but try to attract as many customers as possible through the ability of the marketers owned by the bank.

To be the best, banking always tries to fulfil all social needs by improving the banking products they have. Even the banks sometimes have to create new products in order to expand their market segment. The progress of this product is in line with the increasing social needs in the banking world. These new products actually created because of the interaction between the bank and community. follows:

The number of customers of PT. Bank Pembangunan Daerah Kalimantan Timur as

Sumardjono and Rio Cipto Sulton. Strategy Formulation of PT. Bank Pembangunan Daerah Kalimantan Timur 


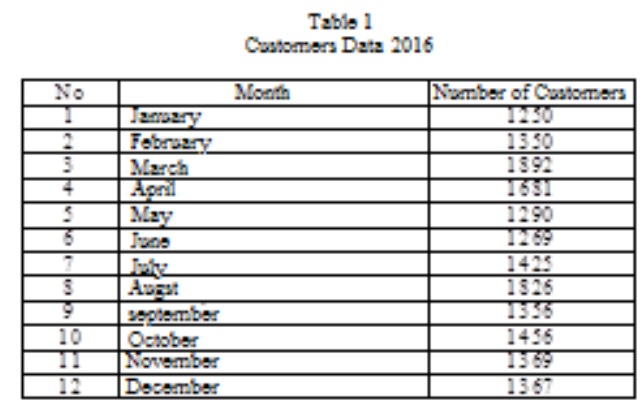

Table 1 shows customer data that fluctuates and near to decrease, it indicates that the achievement of targets cannot be carried out, so for that we need a strategy in order to increase the profit that has been targeted by the company.

\section{Research Purpose}

Based on the formula above, the objectives of this study are:

1. To find out the factors which become main strengths and weaknesses of PT. Bank Pembangunan Daerah Kalimantan Timur.

2. To find out the factors which become opportunities and threat weaknesses of PT. Bank Pembangunan Daerah Kalimantan Timur

3. To find out the right strategies to be implemented at PT. Bank Pembangunan Daerah Kalaimantan Timur.

\section{LITERATURE REVIEW}

\section{Strategy}

According to David, Fred R. (2008), strategy is a potential action that requires top management decisions and large amounts of company resources. In addition, the strategy influences the long-term development of the company, usually for the next five years, and herefore oriented towards the future. Strategies have multifunctional or multidivisional consequences and need to consider both external and internal factors faced by the company.

\section{Strategic Management}

According to Umar, Husein (2002: 17). Strategic Management is the art and science of formulating, implementing, and evaluating strategic decisions in functions that enable an organization to achieve its goals in the future.

\section{Strategic Formulation}

According to Supratikno, Hendrawan (2003: 9), the most influential stream in strategic formulation process referred to the management literature as "the design school". This stream says that the organization's strategy is basically attempt to create a "fit" or "match" between the organization's internal capabilities and external opportunities. The analytical tool helps to create "fit and macth" is SWOT analysis.

\section{Mission and Vision Statement}

According to David, Fred R. (2009: 16). There are many organizations develop both mission statements and vision statements. While the mission statement answers the question, "What is our business?" The vision statement tries to give the answer to the question, "What do we want to be?" Many organizations have both statements. 


\section{External Audit}

According to David, Fred R (2009: 120). "The purpose of external audit is to develop a limited opportunities list that can benefit a company and threats that must be avoided".

\section{Internal Audit}

According to David, Fred R (2009: 120). "The purpose of an external audit is to develop a limited power list that can benefit a company and weaknesses that must be avoided".

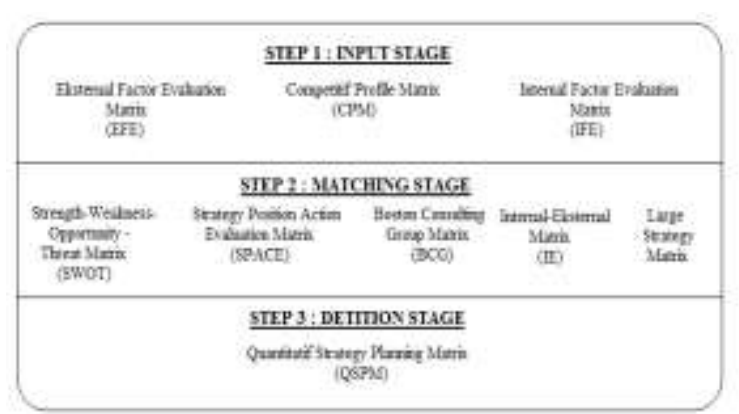

Figure 1. Analysis Framework Strategy Formula

\section{METHODS / TYPES OF RESEARCH}

The research method in this paper is a descriptive method with a field survey approach. Descriptive method discusses problems by describing characteristics, describing and interpreting as a conclusion. The purpose of the field survey approach is to obtain facts from existing symptoms and seek information relevant to the research objectives. This research method can be used with more aspects and wider than other methods. This method also provides up-to-date information so that the development of science and more applied to various problems.

\section{Research Objective}

The object of this study is PT. Bank Pembangunan Daerah Kalimantan Timur, at Jl. Jenderal Sudirman No. 33 Samarinda, Kalimantan Timur.

\section{Population and Sampling}

The sampling technique aims to determine the limits for the population that you want to study. This study used a purposive sampling technique, i.e. taking sample members based on certain considerations. The members of this study sample are management officials of PT. Bank Pembanngunan Daerah Kalimantan Timur, 5 head office employees. Because managers know for sure and they are totally responsible for the strategy which taken by the company.

\section{Research Variable}

According to Sugiono (2006: 31), research variable is basically anything applied being studied by researcher.

The variables of this study are opportunity factors and external threats that are being or will be faced by the company and the internal strengths and weaknesses of the company that are identified as independent variables that determine each change of dependent variable, i.e. company's strategy.

Sumardjono and Rio Cipto Sulton. Strategy Formulation of PT. Bank Pembangunan Daerah Kalimantan Timur 


\section{Internal factors of the company:}

1. Strengths

Strength is the resources, skills, or other advantages that are relative to competitors and the market needs that the company wants to serve. Strength is a special competency that provides a comparative advantage for companies in the market.

2. Weaknesses

Weakness is limitation or deficiency of resources, skill, and capability that interrupts the company's effective performance.

\section{External factors of the company:}

1. Opportunity is an important situation that is beneficial in a company environment.

2. Threat is very important situation that is not profitable in a company environment.

\section{The company's main competitors and competitive factors:}

1. The company's main competitors

2. Identify other companies which are considered as the main competitors.

3. Competitive factors of a company

4. Factors that considered to influence the success of a company. These factors include internal and external issues

\section{Competitive Position and Market Growth:}

1. Competitive position Identify competitive position of a company compared to its competitors.

2. Market growth Identify if the market is still growing, and its growth is going fast or not.

\section{Types of Data and Data Collective Methods}

\section{Types of Data}

Types of Data used in this study:

1. Primary data

Primary data is an obtained data from the first source of individuals such as interviews or questionnaires carried by researchers. In this study, research data was obtained through the results of company's internal processing identified as independent variables that determine each change of the dependent variable, i.e. company's strategy.

2. Competitive Profile Matrix (Competitive Profile Matrix-CPM)

Factors that influence CPM matrix consist of critical success factors.

3. SWOT Matrix (Strength, Weakness, Opportunity, Threath)

Internal factors of a company:

1. Strengths: company power that place a company at advantage in functional fields, including management, marketing, finance or accounting, production or operational, research and development, and management information system

2. Weaknesses: characteristic that place a company at disadvantage in functional fields, including management, marketing, finance, or accounting, production or operational, research and development, and management information system

External factors of a company:

1. Opportunities: elements in economic, social, cultural, demographic, government, technological laws, and competition power. 
2. Threats: elements in government and law, competition strength and technology can be threats to a company.

3. Grand Strategy Matrix (GS).

Factors that influence GS matrix:

\section{The Input Stage}

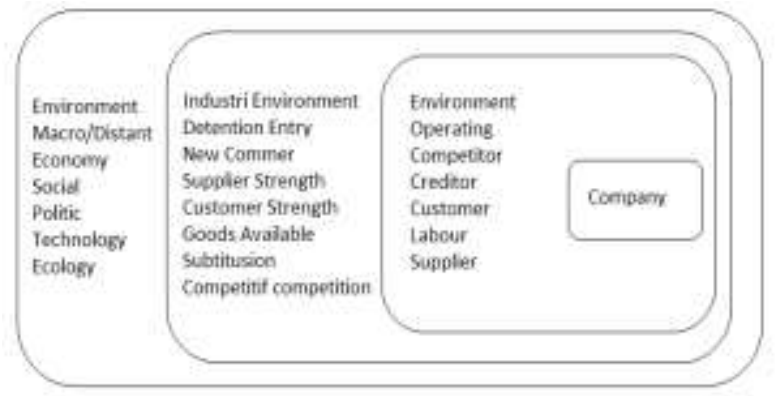

In evaluating strategic factors at this stage, External Factor Evaluation Matrix, Evaluation Matrix, Internal Factors, and Competitive Profile Matrix are used.

This stage has been divided into EFE, IFE, and CPM Matrix, also how to specify its weight, rating, and score.

1. CPM Matrix (Competitive Profile Matrix)

CPM matrix is a tool used to identify the company's main competitors as well as their strengths and weaknesses in relation to the strategic position of competitor companies.

2. This CPM matrix is organized based on:

Select and specify the two closest competitors of the company

Select and specify factors for company success

\section{Matching Stage}

After collecting all informations that influence the continuity of a company, the next step is to utilize all quantitative formulation strategies. The matrix used as follows:

\section{TOWS Matrix}

This matrix can illustrate clearly how the opportunities and external threats faced by a company can be adjusted to the strengths and weaknesses it has. Threats-Opportunities-Weaknesses-Strengths (TOWS) Matrix is an important matching tool to help managers develop four types of strategies. This matrix can produce four possible alternative strategies as shown in the following figure.



Figure 2. TOWS Matrix

Sumardjono and Rio Cipto Sulton. Strategy Formulation of PT. Bank Pembangunan Daerah Kalimantan Timur 
- $\quad$ SO Strategies (SO = Strength-Opportunity)

- WO Strategies (WO = Weakness-Opportunity)

- $\quad$ ST Strategies (ST = Strength-Threat)

- WT Strategies (WT = Weakness-Threat)

\section{RESULT AND DISCUSSION}

\section{Vision and Mission}

Vision "Become Strong, Competitive And Contributive True Regional Champion In Supporting Quality Regional Economic Growth."

\section{Mission}

1. Strengthen institution resilience through the implementation of quality compliance and risk management.

2. Develop solutions and technology-based banking products and services.

3. Become a major supporter of economic development programs and support the empowerment of the people's economy.

4. Increase social awareness for community and surrounding.

5. Maintain and enhance the reputation of the Bank.

\section{Review}

Step 1: The Input Stage

\section{CPM Matrix (Competition Profile Matrix)}

This CPM matrix provides information about the company's competitive position compared to its main competitors. To get profile data of PT. Bank Pembangunan Daerah Kalimantan Timur is directly obtained from the leadership because the author works at the bank, for both competitor banks the author conducted interviews with the staff of Human Resource Management to get information relating to research data. The competitors to PT. Bank Pembangunan Daerah Kalimantan Timur are PT. Bank Pembangunan Daerah Kalimantan Barat and PT. Bank Pembangunan Daerah Kalimantan Selatan.

Step 1 of The Input Stage in this research can be seen in the table below:

Table 2. CPM Matrix

\begin{tabular}{|l|c|c|c|c|c|c|c|}
\hline \multirow{2}{*}{$\begin{array}{l}\text { Critical } \\
\text { Sucsess } \\
\text { Factor }\end{array}$} & \multirow{2}{*}{ Weight } & \multicolumn{2}{|c|}{ PT. BPD KALTIM } & \multicolumn{2}{l|}{ BPD KALBAR } & \multicolumn{2}{c|}{ BPD KALSEL } \\
\cline { 3 - 8 } & & Rating & Score & Rating & Score & Rating & Score \\
\hline Asset & 0.20 & 4 & 0.80 & 3 & 0.60 & 3 & 0.6 \\
\hline Human Resource & 0.15 & 3 & 0.45 & 3 & 0.45 & 2 & 0.3 \\
\hline Product & 0.17 & 3 & 0.51 & 3 & 0.51 & 3 & 0.51 \\
\hline Technology & 0.15 & 2 & 0.30 & 2 & 0.30 & 2 & 0.3 \\
\hline Brand Image & 0.15 & 3 & 0.45 & 2 & 0.30 & 2 & 0.3 \\
\hline Market Share & 0.18 & 3 & 0.54 & 2 & 0.36 & 2 & 0.36 \\
\hline & 1.00 & & 3.05 & & 2.52 & & 2.37 \\
\hline
\end{tabular}

Sumardjono and Rio Cipto Sulton. Strategy Formulation of PT. Bank Pembangunan Daerah Kalimantan Timur 
Information:

$1=$ Major Weakness (low)

$2=$ Minor Weakness (medium)

$3=$ Minor Strength (high)

$4=$ Major Strength (heavy)

Information:

1. PT. Bank Pembangunan Daerah Kalimantan Timur has more assets than its competitors.

2. PT. Bank Pembangunan Daerah Kalimantan Timur has qualified and professional human resources more than both competitor banks mentioned above.

3. PT. Bank Pembangunan Daerah Kalimantan Timur provides banking products in accordance with applicable $\mathrm{BI}$ provisions and is able to compete in market share.

4. PT. Bank Pembangunan Daerah Kalimantan Timur provides up-to-date technology to support its operational activities.

Brand Image

Table 3. IFAS Matrix

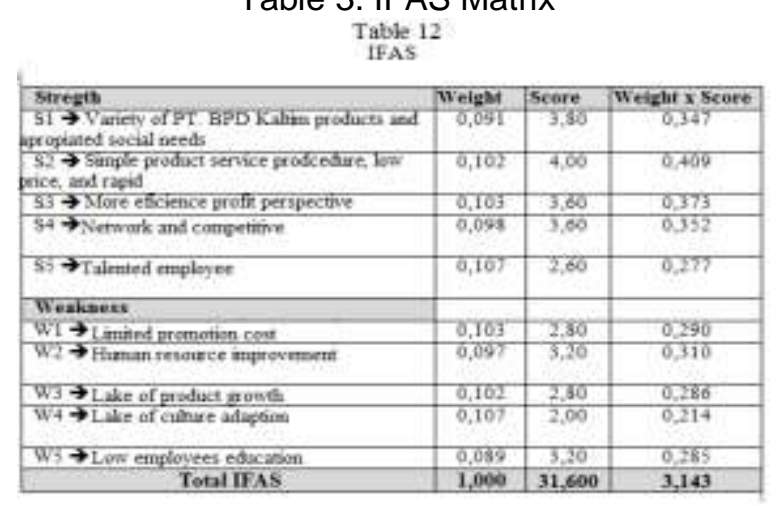

Information:

1. Strengths

In strengths, the highest weight is a product that has good and durable quality, because product quality is concerned by PT. Bank Pembangunan Daerah Kalimantan Timur. The highest rating on strengths is simple product service procedure, low price and rapid with 4.09 highest point.

2. Weaknesses

In weaknesses, the quality of human resources still needs to be improved. The highest rating on weakness is human resources quality that still needs to be improved with the 3.10 highest point of calculation results of IFE matrix as a whole obtained with 3.143 total score which indicates that the company's internal position is quite strong. The company is quite capable using its strengths and solving its weaknesses well.

Sumardjono and Rio Cipto Sulton. Strategy Formulation of PT. Bank Pembangunan Daerah Kalimantan Timur 
Table 4. EFAS Matrix

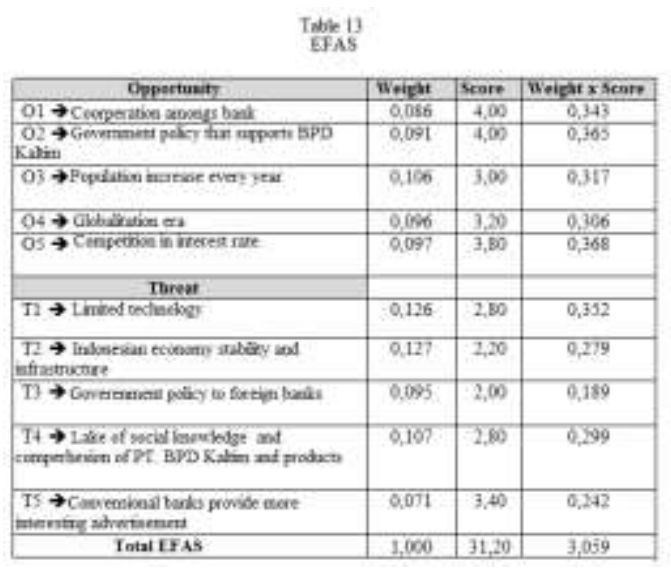

Information:

1. Opportunities

The highest weight of opportunities is the presence of government policies that support the existence of PT. Bank Pembangunan Daerah Kalimantan Timur at the 0.365 highest point, because PT. Bank Pembangunan Daerah Kalimantan Timur supported by regional government policies.

2. Threats

The highest weight of opportunities is the advertisements which presented by conventional banks are more attractive, because by competitors appearance will affect the company existance with the 0.242 highest point, therefore PT. Bank Pembangunan Daerah Kalimantan Timur must advertise regularly through print and electronic media.

The calculation results of all external strategic factors produce 3.059 total score (number of opportunity scores plus threat scores). This shows that the external situation of the company above the average is that the company is able to respond to external factors by utilizing the opportunities that exist to overcome the threat. From total value, it can be concluded that the company is in a high position at facing opportunities and threats with the total score weighted higher than the average value of 3.00 .

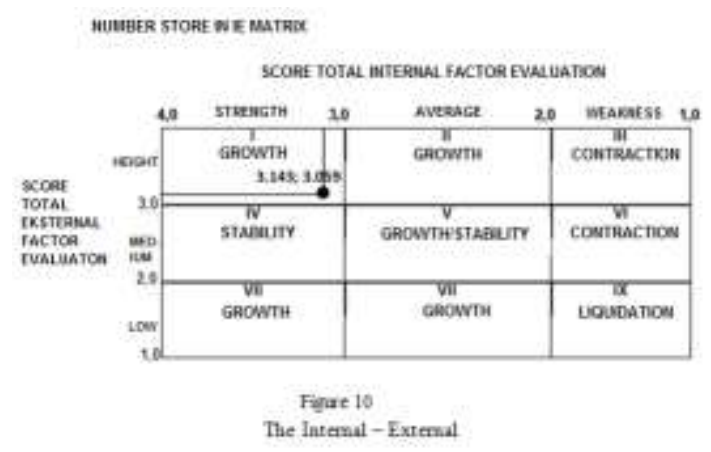

Figure 3. IE Matrix

Information:

1. Quadrant I, II, IV = Grow and Develop = Market Development.

2. Quadrant III, V, VII = Keep and Maintain = Market Penetration, Product Development

3. Quadrant VI, VIII, IX = Harvest = Enjoy Results.

Information:

In the figure above it can be seen that the total coordinates of evaluation scores of internal and external factors are placed in cell I, II, or IV, it is the impact of growth

Sumardjono and Rio Cipto Sulton. Strategy Formulation of PT. Bank Pembangunan Daerah Kalimantan Timur 
strategy. The matrix column, which is the total evaluation score of internal factors, shows the strength of weak business position of PT. Bank Pembangunan Daerah Kalimantan Timur in market competition. While the row matrix, as total score evaluation of external factors, represents the high and low attractiveness of the market.

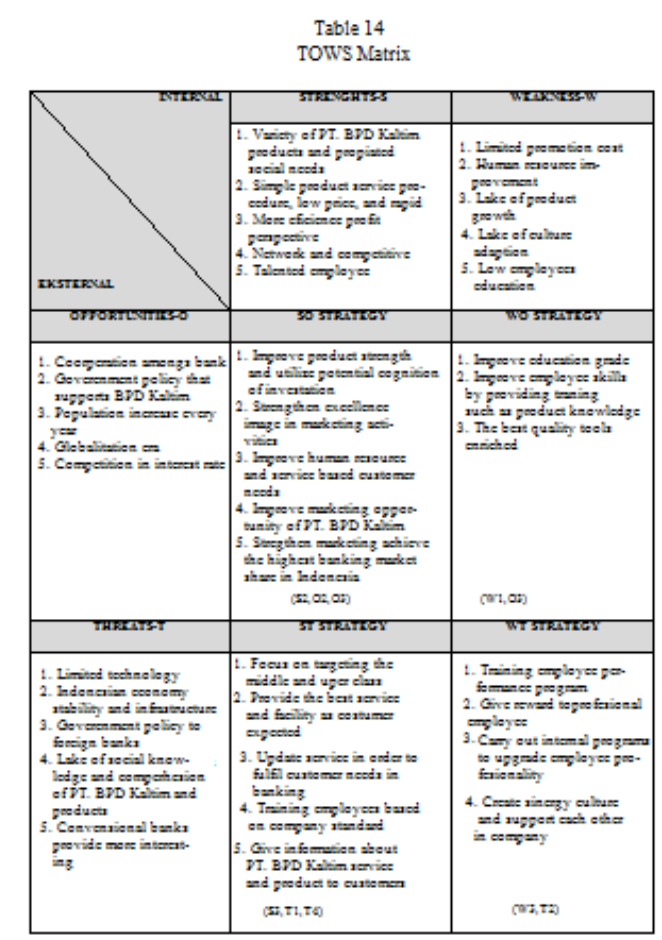

Figure 4. TOWS Matrix



Figure 5. Space Matrix

Sumardjono and Rio Cipto Sulton. Strategy Formulation of PT. Bank Pembangunan Daerah 
Calculation:

CA average

FS average

IS average

$$
\begin{aligned}
& =-11: 4=-2.75 \\
& =15: 4=3.75 \\
& =12: 3=4.00 \\
& =-10: 4=-2.50
\end{aligned}
$$

ES average

Line $X=C A$ average + IS average $=(-2.75)+4.00=1.25$

Line $\mathrm{Y}=\mathrm{FS}$ average $+\mathrm{ES}$ average $=3.75+(-2.50)=1.25$

\begin{tabular}{|c|c|c|c|c|c|c|c|c|}
\hline Unit & Profit & $\begin{array}{l}\text { Profit } \\
\text { (\%) }\end{array}$ & sevenve & $\begin{array}{r}\text { Pevenve } \\
(\%)\end{array}$ & \begin{tabular}{|c|} 
The Highest \\
Competitor \\
Market 9nare \\
$(\%)$
\end{tabular} & $\begin{array}{l}\text { Market } \\
\text { Share } \\
(96)\end{array}$ & $\begin{array}{l}\text { Restive } \\
\text { Market } \\
\text { Share }\end{array}$ & $\begin{array}{l}\text { Growth } \\
\text { Market } \\
\text { Level }\end{array}$ \\
\hline Fingoso and Accovating Divives & 5,000 & 34.48 & 2,000 & 15.38 & 20 & 5 & 0.25 & 11 \\
\hline Bwinosu and Frating Drivison & 3,500 & 24.14 & 3,000 & 38.46 & 25 & 21 & 0.84 & 12 \\
\hline Teaurg and hemaignal Dirion & 2500 & 17.24 & 1,000 & 7.69 & 15 & 8 & 0.53 & 8 \\
\hline Penhelagy and hismesen Divas & 2500 & 1724 & 2,000 & 15.38 & 30 & 23 & 0.46 & 17 \\
\hline Humen Croinal Diviso & 1,000 & 690 & 3,000 & 23.08 & 30 & 5 & 0.17 & 4 \\
\hline TOTAL & 4,500 & 100.00 & 13000 & 100000 & & & & \\
\hline
\end{tabular}

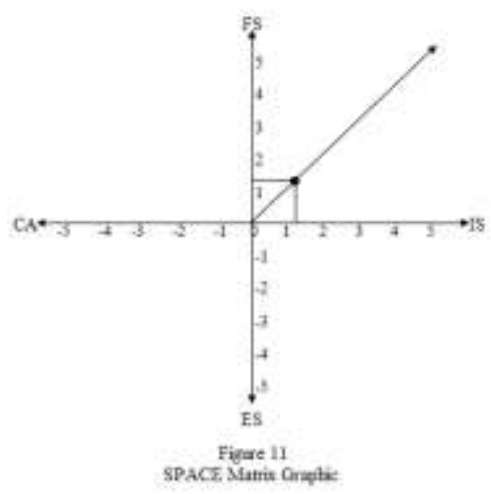

Table 16

PT. BPD Kaltim Division

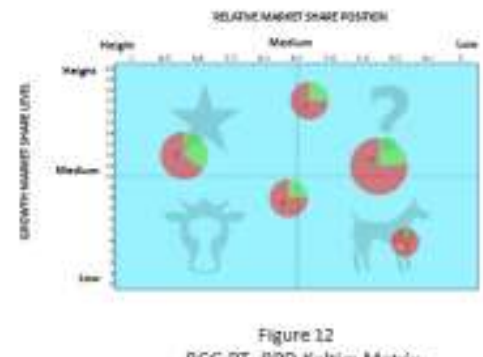

BCG PT. BPD Kaltim Matrix

Figure 5. BCG Matrix

Sumardjono and Rio Cipto Sulton. Strategy Formulation of PT. Bank Pembangunan Daerah Kalimantan Timur 
The Management Journal of BINANIAGA Vol. 03, No. 02, December 2018 PISSN: $2527-4317$

EISSN: $2580-149 x$

Table 5. Strategic Feasibility

\begin{tabular}{|c|c|c|c|}
\hline \multicolumn{4}{|c|}{$\begin{array}{l}\text { Table } 17 \\
\text { Altemative Feasibility }\end{array}$} \\
\hline $\begin{array}{l}\text { Alternative } \\
\text { Strategy }\end{array}$ & \begin{tabular}{|l} 
Appears \\
Froen \\
Matrix
\end{tabular} & \begin{tabular}{|l} 
Feasible \\
Not \\
Feasible
\end{tabular} & Reason \\
\hline $\begin{array}{l}\text { Product } \\
\text { Innovation }\end{array}$ & $\begin{array}{l}\text { CPM \& TOES } \\
\text { Matrix }\end{array}$ & Feasible & $\begin{array}{l}\text { 1. Improve market opportunity } \\
\text { of PT. BPD Kaltim in } \\
\text { Kalimantan Timus } \\
\text { 2. Strengthen marketing to } \\
\text { achieve the highest banking } \\
\text { market share in Indonesia }\end{array}$ \\
\hline $\begin{array}{l}\text { Narket } \\
\text { Penetration }\end{array}$ & $\begin{array}{l}\text { TOWS \& IE } \\
\text { Matrix }\end{array}$ & Feasible & $\begin{array}{l}\text { 1. Variety ofPT. BPD Kaltim } \\
\text { products and apropiated to } \\
\text { social nesds } \\
\text { 2. Simple product service } \\
\text { procedur, low price, and rapid }\end{array}$ \\
\hline $\begin{array}{l}\text { Increasing } \\
\text { number of } \\
\text { Customers }\end{array}$ & \begin{tabular}{|l|} 
CPM \& \\
TOWS Matrix
\end{tabular} & Feasible & $\begin{array}{l}\text { 1. Improvenent imployes skills } \\
\text { by providing training such as } \\
\text { knowledge product } \\
\text { 2. The best quality toots } \\
\text { enriched }\end{array}$ \\
\hline $\begin{array}{l}\text { Service } \\
\text { Improvement }\end{array}$ & TOWS Matrix & Feasible & $\begin{array}{l}\text { 1. Focus on targeting the } \\
\text { middle and uper class } \\
2 \text { Provide the best service and } \\
\text { facility as customers expected }\end{array}$ \\
\hline
\end{tabular}

Table. 6 QSPM
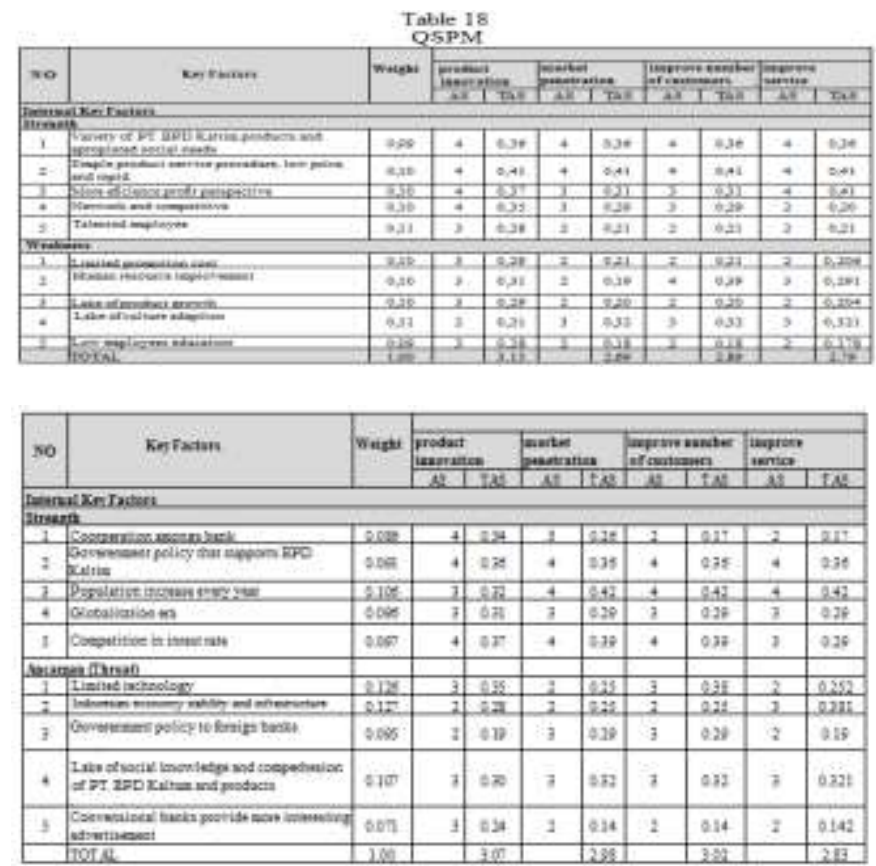

Information:

$1=$ No attraction

$2=$ Low attraction

$3=$ Medium attraction

$4=$ High attraction

Sumardjono and Rio Cipto Sulton. Strategy Formulation of PT. Bank Pembangunan Daerah 
1. Long-term Implementation

Internal and external TAS (Total Attractiveness Score)
a. Product innovation
$3.15+3.07=6.22$
b. Market penetration
$2.69+2.98=5.67$
c. Increasing number of customers
$2.89+3.02=5.91$
d. Service improvements
$2.79+2.83=5.62$

2. Medium Term Implementation

a. Human Resource

b. Share information about product provisions that apply according to the provisions of Bank Indonesia.

c. Product Provide up-to-date knowledge products to employees to be able to dominate banking industry.

d. Marketing Promote activities through the corner of the market in the fields of education, tourism and in collaboration with local governments.

e. Finance Provide a convenience to customers in credit loans according to their needs.

3. Long-term Implementation

a. Human Resource

Provide regular training to employees in order to maintain and improve service to customers.

b. Product

Maintain existing products and improve product innovation to anticipate new products from competitors

c. Marketing

Conduct promotional activities through print and electronic media by using short and clear language in order to attract customers and facilitate with a maximum budget.

d. Finance

Control financial expenditure and manage capital so that it can create profits and anticipate liquidation.

\section{CONCLUSION AND RECOMMENDATION}

\section{Conclusion}

From total results of TAS (Total Attractiveness Score) on QSPM matrix, the product innovation strategy is higher than market penetration and increasing number of customers, therefore a proper strategy is to innovate products, improve services, add or employ recruit employees or experts in support product development.

\section{Recommendation}

1. By knowing the strengths and weaknesses of PT. Bank Pembangunan Daerah Kalimantan Timur, the factors of opportunities and threats from the external environment, PT. Bank Pembangunan Daerah Kalimantan Timur needs to continue all SWOT strategies (S-O, S-T, W-O, and W-T) with discipline and evaluate their effectiveness regularly.

2. In a growth position, management of PT. Bank Pembangunan Daerah Kalimantan Timur is advised to implement market penetration strategy decisions, market development or product development, and integrated strategies such as backward integration, forward integration and horizontal integration. PT. Bank Pembangunan

Sumardjono and Rio Cipto Sulton. Strategy Formulation of PT. Bank Pembangunan Daerah Kalimantan Timur 
Daerah Kalimantan Timur needs to make greater marketing efforts and open up new potential markets both in and out of Jakarta

3. PT. Bank Pembangunan Daerah Kalimantan Timur needs to improve service in accordance with the expectations of its customers, fix the shortcomings of service facilities and infrastructure, develop its products by completing banking facilities and facilities for customers.

\section{REFERENCES}

Afrillita, Nur. 2013. Analisis SWOT dalam Menentukan Strategi Pemasaran Sepeda Motor pada PT. Samekarindo Indah di Samarinda. e-Journal Administrasi Bisnis 2013, 1 (1): 56-70 ISSN 0000-0000, ejournal.adbisnis.fisip-unmul.org (c) Copyright 2013.

Cameron, Kim S., Robert E. Quinn (1999). Diagnosing and Changing Organizational Culture: Based on the Competing Values Framework. Reading, Massachusetts: Addison Wesley.

David, F. R. 2004. Strategic Management. Concept. $7^{\text {th }}$ Edition. Prenhallindo, Jakarta. 2006. Concepts Strategic Management. $10^{\text {th }}$ Edition. Salemba Empat. Jakarta. , 2009. Strategic Management Concept. $12^{\text {th }}$ Edition. Salemba Empat. Jakarta.

Durianto, Darmadi et al. 2003. Inovasi Pasar dengan Iklan yang Efektif. Jakarta, PT Gramedia Pustaka Utama.

Hunger, J. David dan Wheelen, Thomas L, 2008. Manajemen Strategis, Yogyakarta: Andil.

Lesmana, Rosa. 2005. Strategi Pemasaran untuk Meningkatkan Penjualan Perumahan di Green River City Bekasi (Studi Kasus di PT. Artha Bangun Pratama). Jurnal IImiah IImu Manajemen ISSN 2356-2005

Nazwirman, Erna Wulandari. 2016. Analisis SWOT untuk Strategi Pemasaran PT. Indorama Synthetics Tbk. Journal of Economics and Business Aseanomics (JEBA) Volume 1 No. 1, Juli - Desember 2016 P-ISSN 2527-7499 E-ISSN 2528 3634

Pearce, Robinson. 2008. Manajemen Stategi : Formulasi, Implementasi dan Pengendalian, Jilid I, Binapura Aksara. Jakarta.

Putri, Ria Tri Ani, Dwi Novirani, Dwi Kurniawan. 2015. Formulasi Strategi Menghadapi Persaingan Industri Kuliner pada Eins Bistro \& Boutique di Bandung. Jurnal Online Institut Teknologi Nasional No.2 | Vol.03 April 2015.

Santoso, Edi, Rivan. 2017. Strategi Pemasaran Produk Bank Pembiayaan Rakyat Syariah (BPRS). Jurnal Ilmiah Ekonomi Islam, 3 (03), 2017, 157-166 ISSN: 24776157 ; E-ISSN 2579-6534

Stephanie, K. Marrus. 2002. Desain Penelitian Manajemen Strategik. Jakarta: Rajawali Press.

Supratikno, Hendrawan, Anton Wachidin, Widjaja, Sugiarto, dan Darmadi Durianto, 2003, Advance Strategic Management: Back to Basic Approach, Cetakan Pertama. Jakarta: PT Gramedia Pustaka Utama.

Sumardjono and Rio Cipto Sulton. Strategy Formulation of PT. Bank Pembangunan Daerah Kalimantan Timur 
Sugiyono. 2006. Metode Penelitian Kuantitatif, Kualitatif. Bandung: Alfabeta.

Umar, Husein. 2001. Strategic Management in Action. Gramedia Pustaka Utama. Jakarta.

, 2002. Strategic Management in Action. $2^{\text {th }}$ Edition. Gramedia Pustaka Utama. Jakarta.

, 2010. Strategic Management in Action. $3^{\text {th }}$ Edition. Gramedia Pustaka Utama. Jakarta.

Sumardjono and Rio Cipto Sulton. Strategy Formulation of PT. Bank Pembangunan Daerah Kalimantan Timur 
The Management Journal of BINANIAGA Vol. 03, No. 02, December 2018 PISSN: $2527-4317$

EISSN: $2580-149 x$

This page intentionally be emptied.

Sumardjono and Rio Cipto Sulton. Strategy Formulation of PT. Bank Pembangunan Daerah Kalimantan Timur 